\title{
Constitutional Personae
}

\section{Citation}

Cass R. Sunstein, Constitutional Personae (Sept. 23, 2013).

\section{Permanent link}

http://nrs.harvard.edu/urn-3:HUL.InstRepos:16217272

\section{Terms of Use}

This article was downloaded from Harvard University's DASH repository, and is made available under the terms and conditions applicable to Open Access Policy Articles, as set forth at http:// nrs.harvard.edu/urn-3:HUL.InstRepos:dash.current.terms-of-use\#OAP

\section{Share Your Story}

The Harvard community has made this article openly available.

Please share how this access benefits you. Submit a story.

Accessibility 
Preliminary draft 9/23/13

All rights reserved

\title{
Constitutional Personae
}

Cass R. Sunstein*

\begin{abstract}
American constitutional law is dominated by four Constitutional Personae, who can be identified by their inclinations, their temperaments, their sensibilities, and their self-presentations. Indeed, many constitutional debates consist of stylized disagreements among the leading Personae: Heroes, Soldiers, Burkeans, and Mutes. Earl Warren is the iconic Hero; Oliver Wendell Holmes, Jr. is the iconic Soldier; Felix Frankfurter is the iconic Burkean; Alexander Bickel speaks for the Mute. At different times and places, and under different constitutional provisions, liberals and conservatives can be Heroes, Soldiers, Burkeans, or Mutes. While the appeal of one or another Persona undoubtedly has psychological and social sources, the choice of the appropriate Persona, in particular cases, should be a product of the proper theory of constitutional interpretation, which must in turn be chosen on the basis of pragmatic judgments about the magnitude and number of errors.
\end{abstract}

\section{Introduction}

Debates over constitutional law familiarly explore competing theories of interpretation. Should judges follow the original understanding of the Constitution, ${ }^{1}$ or attempt to reinforce democratic processes, ${ }^{2}$ or offer moral readings ${ }^{3}$ ? The differences among competing theories are of course fundamental. But if we investigate the arc of constitutional history, we will discover another set of differences. They involve disparate Constitutional Personae - judicial roles and self-presentations that sharply separate judges (as well as academic commentators). The leading Personae are Heroes, Soldiers, Burkeans, and Mutes. Broadly speaking, Heroes are willing to invoke the Constitution to invalidate state and federal legislation; Soldiers defer to the actions of the political branches; Burkeans favor only incremental change; and Mutes prefer not to decide difficult questions.

\footnotetext{
${ }^{*}$ Robert Walmsley University Professor, Harvard University. I am grateful to Bruce Ackerman, Jack Balkin, Martha Nussbaum, Eric Posner, Geoffrey Stone, David Strauss, and Mark Tushnet for exceedingly valuable comments on an earlier draft. Daniel Kanter also provided excellent comments and valuable research assistance.

${ }^{1}$ See ANTONin SCALIA, A MATtER OF INTERPRETATION (1998).

${ }^{2}$ See John Hart Ely, Democracy And Distrust (1980). The core of the theory can be found in United States v. Carolene Products, 304 U.S. 144, 153 n.4 (1938).

${ }^{3}$ RONALD DWORKIN, FreEdOM's LAW: THE MORAL READING OF THE AMERICAN CONSTITUTION (1997).
} 
The four Personae ${ }^{4}$ help to define not only internal disputes on the Court but also famous cases and entire eras of Supreme Court history. Countless past and present constitutional disputes involve contests among Constitutional Personae. Consider, for example, recent disputes over same-sex marriage, ${ }^{5}$ the Affordable Care Act, ${ }^{6}$ the Voting Rights Act, ${ }^{7}$ and affirmative action. ${ }^{8}$ In all these disputes, and many more, each of the four Personae play important roles (while also cutting across standard ideological and methodological divisions). ${ }^{9}$ We can also identify periods of Supreme Court heroism, soldiering, and Burkeanism (though not muteness), certainly with respect to particular constitutional clauses, and sometimes with respect to the Court in general.

An understanding of the Personae cannot, of course, displace standard theories of constitutional interpretation. On the contrary, the choice of Persona is dependent on the selection of some such theory, certainly as a matter of logic. A particular theory (say, originalism) might lead a judge to be heroic, soldierly, Burkean, or mute, as the controversy and the occasion demand. I shall devote considerable attention to this point and hence to the relationship between the Personae and competing constitutional theories. Nonetheless, an understanding of the Personae provides a novel and illuminating perspective on recurring constitutional debates (or so I shall attempt to show).

It is important to emphasize that the Personae are both abstract and stylized, and no real-world judge "is" one or another of them. To be sure, particular judges can be associated with particular Personae, but any such association is best taken to mean only that on especially prominent occasions, the judge has assumed that Persona, or that the judge shows a tendency to adopt that Persona in the most important and challenging cases. Over the course of a career or even a year, many real-world judges will adopt each of the Personae. Some judges switch their persona from case to case frequently because their preferred theory of interpretation calls for such switching; other judges have a more or less consistent persona because their preferred theory calls for it; still other judges change their stance for strategic or other reasons.

It is important to see that adoption of a Persona need not be opportunistic or manipulative; it is generally an authentic reflection of the role that "falls out" of the judge's preferred theory of interpretation. Nonetheless, it cannot be denied that a judge might adopt a Persona for strategic reasons. For example, a judge might prefer in the abstract to be a Hero, but in light of relevant constraints (such as precedent, internal dynamics on a multimember court, or anticipated public reaction), she might write as a Burkean -- with the hope that the Burkean path might eventually produce the same result

\footnotetext{
${ }^{4}$ Cicero also spoke of four personae, but in a quite different context and for quite different purposes. See Christopher Gill, Personhood and Personality: The Four-Personae Theory in Cicero, De Officiis I, 6 OXFORD STUD. IN ANCIENT PHIL. 169 (1988).

${ }^{5}$ United States v. Windsor, 133 S. Ct. 2675 (2013).

${ }^{6}$ Nat'l Fed'n of Indep. Bus. v. Sebelius, 132 S. Ct. 2566 (2012).

${ }^{7}$ Shelby County v. Holder, 133 S. Ct. 2612 (2013).

${ }^{8}$ Fisher v. University of Texas, 133 S. Ct. 2411 (2013).

${ }^{9}$ See below.
} 
that heroism would dictate. Muteness might also be strategic, a form of biding one's time until the time is right. ${ }^{10}$

As we shall also see, a Persona might be a reflection of a judge's actual thinking or instead a judge's preferred self-presentation. A judge might, for example, write and present herself as a Burkean even though her actual conception of the judicial role is heroic. Few judges are likely to say or think, "I am a Burkean," but a judge might well have an explicit or implicit account of the judicial role that leads to Burkean votes and opinions. Such a judge would be likely to have a Burkean self-presentation. No judge self-identifies as a Mute, but all judges think that on occasion, silence is appropriate, and when they do, they are self-conscious Mutes. Most judges do have a soldierly conception of their role, at least on certain occasions. And while no judge will announce, "I am a Hero," many judges do believe that the Constitution sets out ambitious principles of one or another kind, and that it is appropriate for judges to invoke those principles even if the result is to invalidate legislation. In especially interesting cases, a judge might present himself as a Soldier, and that presentation might even reflect his self-understanding - but the judge might be taken as a Hero in the relevant community. As we will see, a Persona might also reflect not a judge's self-understanding or self-presentation, but how a judge is received by some, many, or all members of the community.

The remainder of this Essay is organized as follows. Part II describes the four Personae. Part III sets out stylized conflicts among the Personae, describing their standard positions and conflicts. Part IV investigates how different theories of interpretation can lead to different Personae. Part V discusses the relationship between Personae and what is sometimes described as "judicial ideology." Part VI discusses how to choose a Persona, with an emphasis on the logical priority of the appropriate theory of interpretation.

\section{Heroes, Soldiers, Burkeans, and Mutes}

\section{A. Heroes}

Because of its importance and social salience, the heroic Persona may be the most familiar. The defining characteristic of Heroes is that they are entirely willing to invoke an ambitious understanding of the Constitution to invalidate the decisions of the federal government and the states. Heroes come in many varieties, but whatever their favored approach to constitutional interpretation, Heroes believe in an imperial and potentially transformative role for the federal judiciary in the Constitution's name.

Within the categories of Heroes and heroism, we can find significant differences of degree, from relatively modest Heroes who are willing to strike down acts of Congress without having major reformist aims, to more far-reaching Heroes (Superheroes?) who have large-scale visions and are willing (and perhaps even eager) to embark on

\footnotetext{
${ }^{10}$ While the focus throughout is on American constitutional law, the four Personae can be found in countless legal systems. For example, the Israel judge Aharon Barak is a well-known Hero, see AHARON BARAK, THE JUdGe IN A DEMOCRACY (2008), and the South African Constitutional Court has often been heroic, see THEUnis RouX, THE Politics of PRINCIPLE (2013).
} 
significant projects of social change. To sharpen the category, I will generally understand Heroes to have a high degree of theoretical ambition, with an acknowledgement that their ambition may stem from disparate theories of constitutional interpretation. Both originalists and nonoriginalists can be Heroes; we could imagine Second Amendment Heroes, or Equal Protection Heroes, who draw either on their preferred account of the original understanding or on a moral reading of both provisions.

All Heroes can be considered "activist" in the distinctive sense that they are willing to use the Constitution to strike down acts of Congress and of state legislatures. ${ }^{11}$ It is important to see that as used here, the term "heroic" should not be taken to be one of approval; it is merely a descriptive term. In ordinary language, soldiers can of course be heroes as well, and while I aim to distinguish them here, we shall encounter some interesting alliances and antagonisms between the Hero and the Soldier.

Brown v. Board of Education ${ }^{12}$ is the iconic heroic decision, and its author, Chief Justice Earl Warren, is the iconic heroic judge. ${ }^{13}$ The Warren Court was the Court's iconic heroic era, helping to define a conception of the federal judiciary for a generation and more ${ }^{14}$ But other eras have been heroic too, and many judges have been heroic, at least on prominent occasions. John Marshall was the original judicial hero, ${ }^{15}$ especially insofar as Marbury v. Madison ${ }^{16}$ established the institution of judicial review. ${ }^{17}$ The Dred Scott decision ${ }^{18}$ is an important part of the constitutional anticanon, ${ }^{19}$ and even if it is egregiously wrong, it reflects a large-scale vision of the constitutional settlement, and so is unquestionably heroic in the sense in which I use that term. The Lochner era had many heroic moments (even if some of the justices on the Lochner Court understood and presented themselves as Soldiers or Burkeans). ${ }^{20}$ For decades, William Brennan ${ }^{21}$ and Thurgood Marshall ${ }^{22}$ counted as exemplary Heroes.

\footnotetext{
${ }^{11}$ For this definition of activism, see LEE EPSTEIN ET AL., THE BEHAVIOR OF FEDERAL JUdGES (2013).

12347 U.S. 483 (1984).

${ }^{13}$ See Jim NeWton, Justice for All: EARl WARREn AND the NATiOn He MAde (2007).

${ }^{14}$ See Morton Horwitz, THE W ARren COURT AND THE PURSUIT OF Justice (1994).

${ }^{15}$ See in this vein JeAn EdWARD SMITH, John MARShall: DeFInER OF A NATION (1998).

${ }^{16} 5$ U.S. 137 (1803).

${ }^{17}$ Chief Justice Marshall was also a complex Hero in the sense that many of his decisions did not involve invalidation of the actions of the political branches, but instead gave the national government room to maneuver and thus count as soldierly (in the sense in which I am using that term). See Smith, supra note. McCulloch v. Maryland, 17 U.S. 316 (1819), is of course the most famous decision in this vein. A more soldierly decision is Gibbons v. Ogden, 22 U.S. 1 (1824).

${ }^{18}$ Dred Scott v. Sandford, 60 U.S. 393 (1857).

${ }^{19}$ See Jamal Greene, The Anticanon, 125 HARV. L. REV. 379, 406-12 (2011).

${ }^{20}$ For different perspectives, see HowARD GILMAN, THE CONSTITUTION BESIEGED (1992); PAUL KENS, LOCHNER V. NEW YORK: ECONOMIC REGULATION ON TRIAL (1998); DAVID BERNSTEIN, REHABILITATING LOCHNER (2012).

${ }^{21}$ See, e.g., New York Times v. Sullivan, 376 U.S. 254 (1964).

${ }^{22}$ See, e.g., San Antonio School Dist. v. Rodriguez, 411 U.S. 1, 70 (1973) (Marshall, J., dissenting).
} 
With his willingness to offer large pronouncements about values such as liberty and dignity, ${ }^{23}$ Justice Anthony Kennedy may well the most heroic member of the current Court, ${ }^{24}$ though Antonin Scalia ${ }^{25}$ and Clarence Thomas have heroic moments and tendencies. ${ }^{26}$ In recent years, heroic judges have voted to invalidate the Affordable Care $\mathrm{Act}^{27}$ and university affirmative action programs. ${ }^{28}$

Disparate constitutional provisions provide the occasions for heroism, and Heroes qualify as such with respect to particular provisions, not the Constitution as a whole. (General heroism, as I am understanding it here, would be difficult to imagine, because it fits with no recognizable theory of constitutional interpretation.) There are Free Speech Heroes, ${ }^{29}$ Equal Protection Heroes, ${ }^{30}$ Due Process Heroes, ${ }^{31}$ Religious Liberty Heroes, ${ }^{32}$ Commerce Clause Heroes, ${ }^{33}$ Second Amendment Heroes, ${ }^{34}$ Executive Power Heroes, ${ }^{35}$ Takings Heroes, ${ }^{36}$ Standing Heroes, ${ }^{37}$ and many more. A judge might endorse heroism with respect to one provision but firmly reject it with respect to others. Indeed, that pattern is common. When the Court as a whole is heroic for certain periods, its heroism can be found in connection with particular provisions - with, for example, the Warren Court using the First Amendment and the Equal Protection Clause, ${ }^{38}$ and the Lochner Court invoking the Commerce Clause and the Due Process Clause. ${ }^{39}$

Heroism has enthusiastic academic defenders, ${ }^{40}$ and academic commentators are often inclined to lionize judicial Heroes and to argue for more in the way of heroism. ${ }^{41}$ But it is important to see that heroism's academic defenders are highly diverse in both their ideological orientation and their theory of interpretation. In the aftermath of the era that Brown helped to define, many academic commentators saw that decision as

\footnotetext{
${ }^{23}$ See, e.g., United States v. Windsor, 133 S. Ct. 2675 (2013).

${ }^{24}$ See, e.g., Romer v. Evans, 517 U.S. 620 (1996); Lawrence v. Texas, 539 U.S. 558 (2003); United States v. Windsor, 133 S. Ct. 2675 (2013). For a general account, see FrANK COLUCCI, JUSTICE KENNEDY'S JURISPRUDENCE (2009).

${ }^{25}$ District of Columbia v. Heller, 554 U.S. 570 (2008).

${ }^{26}$ Fisher v. University of Texas, 133 S. Ct. 2411, 2422 (2013) (Thomas, J., concurring)

${ }^{27}$ See Nat'l Fed'n of Indep. Bus. v. Sebelius, 132 S. Ct. 2566, 2642 (2012) (Scalia, Kennedy, Thomas, Alito, JJ, dissenting).

${ }^{28}$ See Fisher, 133 S. Ct. at 2422 (2013) (Thomas, J., concurring).

${ }^{29}$ See, e.g., New York Times v. Sullivan, 376 U.S. 254 (1964).

${ }^{30}$ Brown v. Bd. of Educ., 347 U.S. 483 (1954).

${ }^{31}$ Roe v. Wade, 410 U.S. 113 (1973).

${ }^{32}$ Engel v. Vitale, 370 U.S. 421 (1962).

${ }^{33}$ See United States v. Morrison, 529 U.S. 598 (2000).

${ }^{34}$ District of Columbia v. Heller, 554 U.S. 570 (2008).

${ }^{35}$ See Myers v. United States, 272 U.S. 52 (1926).

${ }^{36}$ See Lucas v. S.C. Coastal Council, 505 U.S. 1003 (1992).

${ }^{37}$ Lujan v. Defenders of Wildlife, 504 U.S. 555 (1992).

${ }^{38}$ See note supra.

${ }^{39}$ See note supra.

${ }^{40}$ See RONALD DWORKIn, JUSTICE IN ROBES (2008)

${ }^{41}$ See Laurence H. TRibe \& Michael C, Dorf, On Reading the Constitution (1999).
} 
establishing the appropriate judicial role, and they hoped for many Browns, vindicating large-scale conceptions of liberty or equality, and reforming society accordingly. ${ }^{42}$

Ronald Dworkin's discussion of Hercules, rendering moral judgments, is the most sustained academic elaboration of the heroic judicial Persona. ${ }^{43}$ Emphasizing the heroic role of judges in promoting democratic self-government, John Hart Ely dedicates his influential book to Earl Warren, specifically observing that "you don't need many heroes if you choose carefully." 44 Those who embrace Ely's democracy-reinforcing theory of judicial review are likely to support heroism, at least some of the time.

More recently, those with a libertarian conception of the Constitution, like Randy Barnett ${ }^{45}$ and Richard Epstein, ${ }^{46}$ are seeking to promote judicial heroism through aggressive use of certain constitutional provisions in the interest of a particular conception of liberty. Efforts to promote a broad understanding of the Takings Clause are meant to produce a form of heroism. ${ }^{47}$ Contracts Clause heroism has also been vigorously defended. ${ }^{48}$ Consider too recent efforts to understand the Commerce Clause and the Necessary and Proper Clause in such a way as to impose serious restrictions on congressional authority. ${ }^{49}$ As we shall shortly see, originalists can certainly be Heroes, and there are Burkean Heroes as well (though their Burkeanism severely qualifies their heroism).

\section{B. Soldiers}

At the opposite pole from Heroes are Soldiers, who argue in favor of following orders. The defining feature of the judicial Soldier is a willingness to defer to the will of his superiors, typically understood as the political branches of government. ${ }^{50}$ In ordinary language, of course, the idea of the Soldier can be understood in many different ways. As I understand them here, Soldiers are deferential, and they understand or portray themselves to be subordinates, essentially doing what others have told them to do. (Originalists, who also portray themselves as Soldiers, provide an important wrinkle, to which I will turn in due course.)

Justice Oliver Wendell Holmes is a hero to many, and he may well deserve the label. But in terms of Personae, he was largely a Soldier, as reflected in his famous

\footnotetext{
${ }^{42}$ See, e.g., Frank Michelman, The Supreme Court, 1968 Term - Foreword: On Protecting the Poor Through the Fourteenth Amendment, 83 HARV. L. REV. 7 (1969) (arguing for constitutional welfare rights).

${ }^{43}$ See RONALD DWORKIN, LAW's EMPIRE 238-75 (1985).

${ }^{44}$ JOHN HART ELY, DEMOCRACY AND DISTRUST, at v (1980).

${ }^{45}$ See RANDY BARNETT, RECOVERING THE LOST CONSTITUTION (2005).

${ }^{46}$ See RICHARD A. EPSTEIN, TAKINGS (1985).

${ }^{47}$ See id.

${ }^{48}$ See Richard A. Epstein, Toward a Revitalization of the Contract Clause, 51 U. CHI. L. REV. 703 (1984).

49 See Richard A. Epstein, How Progressives Rewrote the Constitution (2006).

${ }^{50}$ This is a familiar theme in the area of statutory interpretation. See Frank H. Easterbrook, Judges As Honest Agents, 33 HARV. J.L. \& PUB. POL'Y 915 (2010).
} 
suggestion, "If my fellow citizens want to go to Hell I will help them. It's my job."51 With his famous dissenting words in Lochner, Holmes helped to define the Persona of the Soldier for more than a century: "a constitution is not intended to embody a particular economic theory, whether of paternalism and the organic relation of the citizen to the state or of laissez faire. It is made for people of fundamentally differing views, and the accident of our finding certain opinions natural and familiar, or novel, and even shocking, ought not to conclude our judgment upon the question whether statutes embodying them conflict with the Constitution of the United States." protection of freedom of speech, ${ }^{53}$ Holmes was a Hero, not a Soldier, but his heroism was limited to that context.

There are many distinguished academic defenses of the Solider. ${ }^{54}$ James Bradley Thayer, the great advocate of judicial deference to the outcomes of political processes, is the most important early expositor of the soldierly conception of the judicial role. ${ }^{55}$ Adrian Vermeule is its most sophisticated contemporary proponent, offering a careful justification of judicial deference to the outcomes of political processes. ${ }^{56}$ Those who embrace populist accounts of constitutional law, who challenge judicial review, or who stress the sovereignty of We the People are likely to endorse the role of the Soldier. ${ }^{57}$ To some people, Soldiers are heroes, because they adopt the proper role and respect the limited place of the judiciary in the constitutional system. While Soldiers can be seen as heroes, they are emphatically not Heroes.

As with heroism, so with soldiering: there are Equal Protection Soldiers, ${ }^{58}$ Due Process Soldiers, ${ }^{59}$ Commerce Clause Soldiers, ${ }^{60}$ Second Amendment Soldiers, ${ }^{61}$ Article II, section I Soldiers, ${ }^{62}$ Takings Soldiers, ${ }^{63}$ Standing Soldiers, ${ }^{64}$ and many more. A judge might endorse soldiering with respect to one provision but reject it with respect to others, and again this pattern is common. If a judge or a court embraces heroism in some

\footnotetext{
${ }^{51}$ Letter from Oliver Wendell Holmes, Jr., to Harold J. Laski (March 4, 1920), reprinted in 1

HOLMES-LASKI LETTERS 248, 249 (Mark DeWolfe ed., 1953).

${ }^{52}$ Lochner v. New York, 198 U.S. 45, 75-76 (1905) (Holmes, J., dissenting).

${ }^{53}$ See, e.g., Abrams v. United States, 250 U.S. 616, 630 (1919) (Holmes, J., dissenting).

${ }^{54}$ See, e.g., J. HARVIE WILKInson, COSMIC CONSTITUTIONAL THEORY (2012).

${ }_{55}^{5}$ James B. Thayer, The Origin and Scope of the American Doctrine of Constitutional Law, 7

HARV. L. REV. 129 (1893)

${ }^{56}$ See AdRIAN VERMEULE, JUdGING UNDER UNCERTAINTY (2006).

${ }^{57}$ See, e.g., LARRY KRAMER, THE PEOPLE ThEMSELVES: PoPUlar CONSTITUTIONALISM AND JUDICIAL REVIEW (2005); MARK TUSHNET, TAKING THE CONSTITUTION AWAY FROM THE COURTS (2000).

${ }^{58}$ Massachusetts v. Murgia, 427 U.S. 307 (1976).

${ }^{59}$ Roe v. Wade, 410 U.S. 113, 171 (1973) (Rehnquist, J.,dissenting).

${ }^{60}$ See United States v. Morrison, 529 U.S. 598 (2000) (Breyer, J.,dissenting).

${ }^{61}$ District of Columbia v. Heller, 554 U.S. 570, 636 (2008) (Stevens, J., dissenting).

${ }^{62}$ See Humphrey's Executor v. United States, 295 U.S. 602 (1935).

${ }^{63}$ See Lucas v. S.C. Coastal Council, 505 U.S. 1003 (1992) (Stevens, J., dissenting).

${ }^{64}$ Lujan v. Defenders of Wildlife, 504 U.S. 555 (1992) (Blackmun, J., dissenting).
} 
domains, it is likely to embrace soldiering in others. There is no logical necessity here, ${ }^{65}$ but the phenomenon is unmistakable, with (for example) the Warren Court and the Lochner Court showing the familiar pattern of selective heroism and soldiering.

To this general account of the Soldier, there is an important qualification. While soldiering as I understand it is associated with judicial deference to the political process, and while I am treating Holmes as the iconic Soldier, other judges, with positions distinctly different from that of Holmes, can claim the mantle of Soldier as well. Insofar as originalists, such as Justice Antonin Scalia and Justice Hugo Black, ${ }^{66}$ seek to speak for We the People, ${ }^{67}$ they can plausibly be described as Soldiers. Indeed, a form of soldiering is built into their self-presentation, and it is a large part of what gives originalism its intuitive appeal. ${ }^{68}$ They too contend that they are simply following orders, not offering moral readings or venturing their own personal accounts of what the Constitution requires. But these kinds of Soldiers are entirely willing to invalidate the actions of the federal government or of the states. To the extent that this is so, it is because they are Soldiers, not in spite of that fact. ${ }^{69}$

We should therefore distinguish between first-order Soldiers, who defer to the judgments of the political process, and second-order Soldiers, who can in a sense count as Hero-Soldiers, willing to trump those judgments when the original public meaning of the Constitution so requires. ${ }^{70}$ In fact, many judges present themselves as second-order Soldiers, even if they reject originalism. They contend that they are merely following the Constitution, and adhering to its mandates, even if the result is to strike down legislation. We can go further. Soldiering is the most fundamental and enduring part of the judicial self-presentation and even of judges' self-understanding. ${ }^{71}$ In referring to Soldiers, I shall be speaking of the first-order variety unless otherwise indicated.

\section{Burkeans}

\footnotetext{
${ }^{65}$ Across-the-board soldering is certainly possible and in some respects appealing, see VERMEULE, supra note, and across-the-board heroism is not unimaginable (though it would be difficult, and it is not easy to see how it might be defended).

${ }^{66}$ See Adamson v. California, 332 U.S. 46, 68 (Black, J., dissenting); Griswold v. Connecticut, 381 U.S. 479, 507 (1965) (Black, J., dissenting).

${ }^{67}$ See Scalia, supra note.

${ }^{68}$ Id.; ORIGINALISM (Steven G. Calabresi ed., 2007). For an illuminating and skeptical empirical study, see Frank CROSS, THE FAILED PROMISE OF ORIGINALISM (2012).

${ }^{69}$ See District of Columbia v. Heller, 554 US 570, 634-35 (2008) ("Constitutional rights are enshrined with the scope they were understood to have when the people adopted them, whether or not future legislatures or (yes) even future judges think that scope too broad").

${ }^{70}$ See, e.g., id.

71 "Formalism," in the pejorative sense, consists of claiming to follow orders, and hence to be soldierly, when some kind of discretionary judgment is being made. See H.L.A. HART, THE CONCEPT OF LAW (1965). Some purported soldiering is a species of formalism in that sense ("faux soldiering"). It follows that a judge may be a Hero but present herself as a second-order Soldier.
} 
Some judges are neither Heroes nor Soldiers but Burkeans, ${ }^{72}$ in the sense that they favor small, cautious steps, building incrementally on the decisions and practices of the past. ${ }^{73}$ Unlike Heroes, who celebrate ambitious accounts of liberty and equality or of the Constitution's structural provisions, those who adopt the Burkean Persona emphasize the limits of large-scale theories.

In dealing with cases involving basic rights, Burkeans do not want to embrace any kind of foundational theory. They argue for careful attention not to abstractions but to traditions, understood at a level of concreteness. Consider Burke's own words, challenging the primacy of abstract theories: "And first of all, the science of jurisprudence, the pride of the human intellect, which, with all its defects, redundancies, and errors, is the collected reason of ages, combining the principles of original justice with the infinite variety of human concerns, as a heap of old exploded errors, would no longer be studied. Personal self-sufficiency and arrogance (the certain attendants upon all those who have never experienced a wisdom greater than their own) would usurp the tribunal." 74

Burkeans also prefer narrow rulings, focused on the facts of particular cases. When sitting on the court of appeals, Chief Justice Roberts captured this preference with an aphoristic summary of the Burkean position in constitutional law: "[I]f it is not necessary to decide more, it is necessary not to decide more." ${ }^{, 75}$ Committed Burkeans will choose Burkeanism in all or most contexts, but some judges might be more cautious (and in a sense Burkean) with respect to Burkeanism itself, insisting that the decision whether to be Burkean is best resolved case-by-case. And in arguing against theoretical ambition and in favor of narrowness, a judge might endorse Burkeanism with respect to one provision but reject it with respect to others. ${ }^{76}$

With their modesty and humility, Burkeans might seem to be close cousins of those Soldiers who are reluctant to invalidate legislation, and alliances are certainly possible between the two Personae. But the two are fundamentally different breeds. Burkeans do not purport to be following anyone's orders or will. They acknowledge and even insist that judges exercise discretion, and to Burkeans, that fact poses a serious problem. Burkeans claim that it is best for judges to exercise their discretion in a way that brackets foundational questions and that ensures small, incremental steps from the status

\footnotetext{
${ }^{72}$ The classic source is Edmund Burke, Reflections on the Revolution in France, in THE PORTABLE EDMUND BURKE 416 (Isaac Kramnick ed., 1999).

${ }^{73}$ See Cass R. Sunstein, Burkean Minimalism, 105 MiCH. L. REV. 353 (2006); see also CASS R. SUNSTEIN, ONE CASE AT A TIME (1999).

${ }^{74}$ Burke, supra note, at 456-57.

${ }^{75}$ The "cardinal principle of judicial restraint" is that "if it is not necessary to decide more, it is necessary not to decide more." PDK Labs., Inc. v. U.S. Drug Enforcement Admin., 362 F.3d 786, 799 (D.C. Cir. 2004) (Roberts, J., concurring in part and concurring in judgment).

${ }^{76}$ See Sunstein, supra note.
} 
quo. They believe that it is important for judges to speak softly and to carry a small stick. ${ }^{77}$

Notwithstanding this point, some Heroes present themselves as Burkeans, contending that a heroic decision is merely an incremental step. ${ }^{78}$ We can certainly imagine at least mildly heroic Burkeans, who are genuinely committed to incrementalism, and who reject the largest theories, but who are nonetheless willing to wield judicial power so as to invalidate legislation. On some occasions, Burkeans might be counted as Heroes as I have used the term, though of a relatively modest variety.

Because of his enthusiasm for tradition, ${ }^{79}$ his commitment to case-by-case judgment, ${ }^{80}$ and his skepticism about large-scale theories, ${ }^{81}$ Justice Felix Frankfurter can be seen as an iconic Burkean. Justice John Marshall Harlan falls in the same category, and in some ways, he may be the most Burkean justice of all. ${ }^{82}$ Justice Sandra Day O'Connor showed strong Burkean inclinations, especially insofar as she liked to focus narrowly on the facts of particular cases. ${ }^{83}$ Chief Justice Roberts has written a number of Burkean opinions, ${ }^{84}$ and hence on prominent occasions, he seems to write as a selfconscious Burkean. Justice Ruth Bader Ginsburg can also be counted as a Burkean, in the sense that she emphasizes the need to focus carefully on both facts and precedents. ${ }^{85}$ From this catalogue, it should be clear that no less than Heroes and Soldiers, Burkeans come in different shapes and sizes. All of them prize narrow, theoretically unambitious rulings, but they may well disagree with one another.

\section{Mutes}

While Burkeans favor narrow and unambitious rulings, the Mute prefers to say nothing at all. Of course no judge can be a consistent or frequent mute, and for that reason, Mutes are infrequent players in the constitutional drama. No member of the Court, past or present, can be characterized as a Mute, and for obvious reasons. But when fundamental issues are at stake, the persona of the Mute will have its attractions.

\footnotetext{
${ }^{77}$ A closely related Persona, not discussed here, is that of the Trimmer, who attempts to steer between the poles. See Cass R. Sunstein, Trimming, 122 HARV. L. REV. 1049 (2009).

${ }^{78}$ United States v. Morrison, 529 U.S. 598 (2000), is a plausible example.

${ }^{79}$ See, e.g., Youngstown Sheet \& Tube Co. v. Sawyer, 343 U.S. 579, 589 (1952) (Frankfurter, J., concurring).

${ }^{80}$ See Rochin v. California, 342 U.S. 16 (1952).

${ }^{81}$ See Youngstown, 343 U.S. at 589 (1952) (Frankfurter, J., concurring).

${ }^{82}$ See Tinsley YARBROUGH, JOHN MARSHALl HARLAN: GREAT DiSSENTER OF THE WARREN COURT (1991).

${ }^{83}$ See, e.g., Grutter v. Bollinger, 539 U.S. 306 (2003). For a popular account, see JOAN BISKUPIC, SANDRA DAY O'CONNOR: HOW THE FIRST WOMAN ON THE SUPREME COURT BECAME ITS MOST INFLUENTIAL JUSTICE (2006).

${ }^{84}$ See United States v. Windsor, 133 S. Ct. 2675, 2696 (2013) (Roberts, J., dissenting).

${ }^{85}$ See Shelby Cnty. v. Holder, 133 S. Ct. 2612, 2632 (2013) (Ginsburg, J., dissenting); Fisher v. Univ. of Tex. at Austin, 133 S. Ct. 2411, 2432 (2013) (Ginsburg, J., dissenting).
} 
Constitutional avoidance is a preferred strategy of the Mute ${ }^{86}$; so too with doctrines of justiciability. With his emphasis on "the passive virtues," through which the Court declines to rule, Alexander Bickel is of course the great theorist of constitutional muteness. $^{87}$

Bickel's own approach emphasizes the strategic and prudential importance of silence, especially on large questions on which the nation is divided. In his account, premature judicial engagement could have a range of harmful consequences for both the nation and the Court. ${ }^{88}$ But others favor muteness on nonstrategic grounds, emphasizing what they regard as the restrictions of Article III. ${ }^{89}$ We can even identify Mute Soldiers, who maintain silence not for prudential reasons, but because of what they see as the commands of the Constitution itself.

Naim v. Naim, ${ }^{90}$ declining to pronounce on the constitutionality of restrictions on racial intermarriage, is the most prominent example of muteness in action. Poe $v$. Ulman, ${ }^{91}$ declining to review a Connecticut law forbidding the sale and use of contraceptives, is another prominent illustration. Hollingsworth v. Perry, ${ }^{92}$ invoking standing to dismiss a challenge to a California law banning recognition of same-sex marriage, is the most recent example; it might well turn out to be this generation's Naim v. Naim. Here yet again, a judge might endorse muteness with respect to one provision (or even controversy), but reject it with respect to others.

\section{Dueling Personae}

It is easy to find examples of the Personae in action. Many constitutional disputes pit them directly against each other. Such disputes are often illuminatingly seen as stylized debates among the four Personae, with one or another judge assuming a particular role, depending on the issue and the context.

\section{A. In the Abstract}

In those disputes, the Hero might invoke a large-scale understanding of equality or liberty, or perhaps of the limits on federal power under Article I. The Soldier responds that courts should defer to the outcomes of the political process unless the constitutional infirmity is quite clear - and concludes that it is not. In this way, the Soldier accuses the

\footnotetext{
${ }^{86}$ See, e.g., Kent v. Dulles, 357 U.S. 116 (1958); Anthony Vitarelli, Comment, Constitutional Avoidance Step Zero, 119 YALE L.J. 837 (2009).

${ }^{87}$ See AlEXANDER BiCKEL, THE LEAST DANGEROUS BRANCH (1965).

${ }^{88}$ See id.

${ }^{89}$ See Antonin Scalia, The Doctrine of Standing As An Essential Element of the Separation of Powers, 17 SUFFOLK U. L. REV. 881 (1983).

${ }^{90} 350$ U.S. 891 (1955).

${ }^{91} 367$ U.S. 497 (1961).

92133 S. Ct. 2652 (2013).
} 
Hero of arrogance or hubris. ${ }^{93}$ The Hero responds, implicitly or explicitly, that the Soldier is willing to disregard clear constitutional constraints on government power, and even to disparage the power of judicial review, usually because what the Hero sees as the Solider's unduly narrow conception of liberty or equality.

The Burkean rejects both positions. Like the Soldier, he accuses the Hero of hubris, but he contends that the Soldier is arrogant in his own way, insofar as he adopts a large-scale posture of deference (which the Burkean regards as grounded in a theory or abstraction of some kind). Against both the Hero and the Soldier, the Burkean insists on the importance of avoiding large pronouncements and the value of engaging carefully with the particular facts. ${ }^{94}$

The Hero might not respond to the Burkean at all, but if he does, he will insist that the Constitution identifies a general principle and that clarity in the law is far preferable to case-by-case obscurantism. ${ }^{95}$ The subtext of the heroic response will be that the Burkean is a coward. The Soldier will regard the Burkean as a temporizer, unwilling to show the proper respect for the democratic branches and leaving a degree of chaos for lower courts to sort out. Where the Burkean sees prudence, the Soldier sees a distinctive kind of arrogance, alongside an inexplicable focus on isolated cases.

The Mute will object to the Hero and the Soldier on grounds similar to those invoked by the Burkean. To the Mute, the proper course is to allow the democratic process to play itself out. Judges ought not to be taking sides. Both invalidation and validation are unacceptable. For the Mute, invalidation is worst of all, because it disables self-government, but validation is also troublesome in light of its legitimating effect in the very domain that people are actively debating. ${ }^{96}$ The Mute is more sympathetic to the Burkean, but she believes that it is simpler and cleaner to stay out of the area entirely rather than to take an incremental step.

Of course the Hero has no patience for the Mute, who (in the Hero's view) is abdicating the judicial role and allowing the Constitution to be ignored in the process. The Soldier insists that the Mute is wrong to stay silent when judges might instead clarify that the issue is for the political process to resolve. The Burkean and the Mute have overlapping concerns, but the Burkean might well believe that a small, incremental step is highly desirable, because it moves the ball in the preferred direction. In the Burkean's view, the Mute is too coy by half.

\section{B. On the Ground}

\footnotetext{
${ }^{93}$ See, e.g., Lochner v. New York, 198 U.S. 45, 60 (1905) (Holmes, J., dissenting); Adkins v. Childrens Hospital, 261 U.S. 525 (1923)(Holmes, J., dissenting); New York Times v. Sullivan, 376 U.S. 254 (1964) (White, J., dissenting); United States v. Windsor, 133 S. Ct. 2675, 2697 (2013) (Scalia, J., dissenting).

${ }_{94}^{94}$ Chicago v. Morales, 527 U.S. 41, 64 (1999) (O'Connor, J., concurring).

${ }^{95}$ For relevant discussion, see Antonin Scalia, The Rule of Law As A Law of Rules, 56 U. CHI. L. REV. 1175 (1989).

${ }^{96}$ See BICKEL, supra note.
} 
For the most vivid recent illustration of these kinds of disputes, consider academic and judicial debates over the constitutionality of restrictions on same-sex marriage. ${ }^{97}$ Heroes would want to insist that such restrictions are unacceptable; they would enlist the Equal Protection Clause in support of that conclusion. Citing the example of Brown, and even more the heroic decision in Loving v. Virginia, ${ }^{98}$ many academic observers have argued in this direction. ${ }^{99}$ By contrast, Soldiers would defer to the political process, saying, in Justice Scalia's words, "the Constitution neither requires nor forbids our society to approve of same-sex marriage, much as it neither requires nor forbids us to approve of no-fault divorce, polygamy, or the consumption of alcohol."100

At least if they are not prepared to defer to traditions, Burkeans would favor narrow, incompletely theorized decisions, leaving the most fundamental questions for another day. For example, the Department of Justice urged a broadly Burkean approach to the constitutional challenge to California's Proposition 9, contending that the Court should decline to resolve the largest questions and rule more narrowly that those states that have recognized same-sex civil unions cannot be permitted to deny those unions the label of "marriage." 101 Under this approach, the Court would bracket the question whether states could refuse to recognize same-sex marriages altogether. For their part, Mutes would use doctrines of justiciability to stay entirely out of this domain, and indeed the Court's use of standing in Hollingsworth is a conspicuous example of the triumph of the Persona of the Mute. ${ }^{102}$

We can find the same Personae in many other constitutional disputes. Roe $v$. Wade is heroic, and those who think the decision was wrong tend to claim the mantle of Soldiers, while Burkeans wish the Roe Court had ruled narrowly, ${ }^{103}$ and of course Mutes would try not to speak at all. Citizens United $^{104}$ is an emphatically heroic decision, and the three non-heroic Personae can easily be found in debates over campaign finance legislation. ${ }^{105}$ Heroes would like to invalidate the Affordable Care Act, ${ }^{106}$ while Soldiers

\footnotetext{
${ }^{97}$ See United States v. Windsor, 133 S. Ct. (2013); AdAM LiPTAK, To HAVE AND UPHOLD: ThE SuPREME COURT AND THE BATTLE FOR SAME-SEX MARRIAGE (2013).

98388 U.S. 1 (1967).

${ }^{99}$ See, e.g., Andrew Koppelman, Why Discrimination against Lesbians and Gay Men Is Sex Discrimination, 69 N.Y.U. L. REV. 197 (1994).

${ }^{100} \mathrm{Id}$.

${ }^{101}$ Brief for the United States as Amicus Curiae at 9-11, Hollingsworth v. Perry, 133 S. Ct. 2652 (2013) (No. 12-144), 2013 WL 769326; see also John Schwartz \& Adam Liptak, U.S. Asks Justices to Reject California's Ban on Gay Marriage, N.Y. TIMES (Feb. 28, 2013), http://www.nytimes.com/2013/03/01/us/politics/administration-to-urge-justices-to-overturn-agay-marriage-ban.html.

${ }_{102} 113$ S. Ct. 2652, 2659 (2013).

${ }^{103}$ See Ruth Bader Ginsburg, Some Thoughts on Autonomy and Equality in Relation to Roe v. Wade, 63 N.C. L. REV. 375 (1985)

${ }^{104}$ Citizens United v. Fed. Election Comm'n, 558 U.S. 310 (2010).

${ }^{105}$ For example, Heroes, Soldiers, and Burkeans can be found in Buckley v. Valeo, 424 U.S. 1 (1976).
} 
would like to uphold it. ${ }^{107}$ Here yet again, Mutes would avoid the question, and Burkeans would seek to rule as narrowly as possible.

\section{The Lessons of History (Of Icons and Anti-Icons)}

Some of these disagreements are influenced by a reading of history and by an understanding of the lesson of canonical examples and counterexamples. ${ }^{108}$ I have noted that Heroes tend to invoke Brown, seeing it as iconic; above all, they do not want to be on the wrong side of history. For such Heroes, New York Times v. Sullivan ${ }^{109}$ and Reynolds v. Sims ${ }^{110}$ are also iconic. For many Heroes, Lawrence v. Texas ${ }^{111}$ is a recent exemplar of an iconic decision (though it can also be characterized as Burkean insofar as it is relatively narrow).

For many Heroes, prominent anti-icons include Plessy v. Ferguson, ${ }^{112}$ Korematsu v. United States, ${ }^{113}$ and Bowers v. Hardwick, ${ }^{114}$ upholding a criminal ban on same-sex marriage. Heroes do not want to write or join another Plessy, and they do not want to replicate the experience in Korematsu or Bowers. Concerned about what they see as judicial abdication during wartime, ${ }^{115}$ many Heroes see Korematsu in particular as an example of what can go wrong when judges operate as Soldiers. Other Heroes regard Wickard v. Filburn ${ }^{116}$ as an anti-icon insofar as it seemed to stretch the meaning of the Commerce Clause in such a way as to give Congress something akin to general police power. Some Heroes are skeptical of NFIB v. Sebelius ${ }^{117}$ and United States v. Carolene Products $^{118}$ insofar as those decisions suggest a degree of deference to legislation that is, in their view, invalid. And for those who believe that Article III imposes sharp limits on standing, United States v. SCRAP is an anti-icon. ${ }^{119}$

${ }^{106}$ See Nat'1 Fed'n of Indep. Bus. v. Sebelius, 132 S. Ct. 2566, 2642 (2012) (Scalia, Kennedy, Thomas, Alito, JJ, dissenting).

${ }^{107} I d$. at 2609 (Ginsburg, J., concurring in part and dissenting in part).

${ }^{108}$ On counterexamples, see Jamal Greene, The Anticanon, 125 HARV. L. REV. 379 (2011).

Authors of counterexamples, and architects of the Anticanon, might be regarded as Villains. No judge, of course, seeks to assume the Persona of the Villain, and so I do not discuss Villains independently here.

109376 U.S. 254 (1964).

110377 U.S. $533(1964)$.

111539 U.S. $558(2003)$.

${ }^{112} 163$ U.S. $537(1896)$

113323 U.S. 214 (1944).

114478 U.S. 186 (1986).

115 See William H. RehNQuist, All The Laws But OnE: Civil Liberties IN WARTime (2000).

${ }^{116} 317$ U.S. $111(1942)$

117567 U.S. (2012).

118304 U.S. 144 (1938)

119412 U.S. 669 (1973). 
For their part, Soldiers tend to see West Coast Hotel v. Parrish, ${ }^{120}$ with its emphasis on judicial deference, as iconic. They think the same for Wickard, because of its deferential approach to the Commerce Clause, and also Katzenbach v. Morgan, with its endorsement of broad deference to congressional power under the Fourteenth Amendment. ${ }^{121}$ For Soldiers, Dred Scott ${ }^{122}$ tends to be the worst decision in the anticanon; they also focus on Lochner v. New York. They are acutely aware of Justice Holmes' cautionary notes about the hazards of reading any particular moral or political theory into the Constitution. Many Soldiers believe that Roe v. Wade is a more recent incarnation of Lochner - and they invoke Roe as a reason for deference to political processes. ${ }^{123}$ Some Soldiers also object to Miranda v. Arizona, ${ }^{124}$ which they regard as a form of lawless Heroism.

It is important to acknowledge, however, that second-order Soldiers understand Lochner, Roe, and Miranda as wrong not merely or even mostly because they invalidated the outcomes of democratic processes, but because they did so without a warrant in the Constitution. Hero-Soldiers reject Lochner and Roe, but they are perfectly willing to strike down limits on the individual right to possess firearms, ${ }^{125}$ to invoke the limited nature of the Commerce Power to strike down the Affordable Care Act, ${ }^{126}$ and generally to reinvigorate restrictions on national power.

Some Burkeans might approve of the Court's sex discrimination cases, in which the Court did not rule broadly all at once, but instead proceeded narrowly and cautiously. ${ }^{127}$ For those Burkeans, the sex discrimination cases are iconic. Burkeans tend to see Roe as objectionable not because it took steps to protect the right to choose, but because of its heroism, embodied in a broad, ambitious ruling, going well beyond what was necessary to decide the case. ${ }^{128}$ In this sense, Roe is a Burkean anti-icon. As noted, Naim v. Naim occupies pride of place in the canon of muteness - and the 5-4 decision in Hollingsworth v. Perry, ${ }^{129}$ understood as an exercise of the passive virtues, promises to join it.

\section{Personae As Literary Devices}

One way to understand the Personae is as rhetorical or literary devices. On this understanding, the Soldier (for example) has a characteristic rhetorical strategy, which is

\footnotetext{
${ }^{120} 300$ U.S. 179 (1937).

121384 U.S. 641 (1966).

${ }^{122}$ See Scott v. Sanford, 60 U.S. 393 (1857).

${ }^{123}$ See Ely, supra note. Ely did not, of course, consistently defend soldiering, but he did so in this context.

${ }^{124} 384$ U.S. 436 (1966)

${ }^{125}$ See District of Columbia v. Heller, 554 U.S. 570 (2008).

${ }^{126}$ See Nat'l Fed'n of Indep. Bus. v. Sebelius, 132 S. Ct. 2566, 2642 (2012) (Scalia, Kennedy, Thomas, Alito, JJ, dissenting).

${ }^{127}$ See, e.g., Reed v. Reed, 404 U.S. 71 (1971).

${ }^{128}$ See Ginsburg, Some Thoughts on Autonomy and Equality in Relation to Roe v. Wade, supra note.

${ }^{129} 133$ S. Ct. 2652 (2013).
} 
to say, "I am compelled to do X, even though I might like to do Y." This strategy might be, and is, used both by first-order and second-order Soldiers. Something similar could be said about Burkeans, who like to say that they are building narrowly on precedent, even if what they are doing is a novelty or a substantial departure, or plausibly characterized as a form of Heroism. To be sure, it is not possible to disguise or feign muteness, but a judge might adopt the Persona of the Mute not because of a commitment to soldiering (as in the view that Article III requires muteness) but as a rhetorical gambit designed as part of "the long game." On this view, the analysis of Constitutional Personae might properly regarded as belonging to the study of judicial politics or even law and literature. ${ }^{130}$

This view is not exactly wrong, and much can be learned by examining the Constitutional Personae in this light. But I am understanding them quite differently here. We might well see the Personae not as a matter of judicial politics or rhetoric, but instead as a product of how different judges actually understand their jobs, and of how they perform those jobs in different contexts. When scholars defend the moral reading of the Constitution, ${ }^{131}$ they are not adopting a mere rhetorical stance, ${ }^{132}$ and the same is true of judges who essentially attempt moral readings. ${ }^{133}$ And when judges operate as Soldiers, it may well be because that Persona captures their understanding of their appropriate role. These points bring us directly to the relationship between theories of interpretation and the Personae.

\section{Personae and Theories of Interpretation}

It is natural to wonder about the relationship between the Constitutional Personae and standard theories of constitutional interpretation. We can already glimpse the basic answer, which is that the standard theories can lead to adoption of one or another of the Personae, depending on the occasion. The words "depending on the occasion" are important. As we shall see, any one of the Personae can fall out of a given theory of interpretation. What matters is exactly when it does so, and here the relevant theory is critical.

\section{A. Theories First, Persona Second?}

Suppose that judges embrace originalism. Such judges would be Mutes when the original understanding of Article III so requires, but they would be Hero-Soldiers if (say) the original understanding of the Commerce Clause or the Fourteenth Amendment calls for invalidation of the Affordable Care Act or affirmative action programs, and they would become Soldiers if the original understanding of the Fourteenth Amendment requires them to uphold restrictions on same-sex marriage. If, by contrast, judges believe in democracy-reinforcement, they might be Heroes on voting rights but Soldiers in the

\footnotetext{
${ }^{130} \mathrm{I}$ am indebted to Adrian Vermeule for making this suggestion.

${ }^{131}$ See DWORKIN, supra note.

${ }^{132}$ At least they are not adopting a rhetorical stance by virtue of defending a moral reading, though of course rhetoric will play a role in their arguments.

${ }^{133}$ See, e.g., Lawrence v. Texas, 539 U.S. 558 (2003).
} 
context of abortion rights. ${ }^{134}$ And if judges endorse a moral reading of Constitution, they might be Heroes with respect to same-sex marriage but Soldiers with respect to economic rights (or vice-versa, depending on their preferred moral theory). ${ }^{135}$

From these examples, it seems clear that many judges will adopt a Persona in accordance with their own theory of constitutional interpretation, whether or not that theory is made explicit. Of course it is true that judges may lack a simple or unitary theory, and they may adopt a Persona on the basis of a collection of considerations that cannot be captured in any kind of theory or "ism."

There are some important (if speculative) qualifications. We have seen that judges may adopt a Persona for strategic reasons. They may speak as Burkeans even though their own theory is Heroic, and the same is true for second-order Soldiers. They may act as Mutes even though they would like to be Heroes (and plan to be). Some judges are undoubtedly drawn to a Persona for social or psychological reasons, and as a matter of causation, the Persona might well antedate their adoption of the relevant constitutional theory. Some judge's self-understanding draws them to the idea of the Soldier, whereas others are led to Burkeanism or to enthusiasm for the Hero. Before they even begin to engage with questions of theory, some people greatly admire the idea of heroic judging (as elaborated, for example, by Dworkin ${ }^{136}$ or Ely ${ }^{137}$ ), whereas to others, that idea seems anathema or a form of hubris. In my view, these social or psychological motivations are important and even foundational, but that claim is highly speculative.

\section{B. Context}

We should also be able to see that different judges may well adopt different Personae in different situations, perhaps because of their preferred approach to constitutional interpretation, perhaps because of contextual considerations. Judges need not be inconsistent or flighty if they are Heroes on one day and Mutes on the next. Whatever their approach, most judges are likely to believe that there is a place for "the passive virtues." ${ }^{38}$ When the nation is sharply divided, they might therefore choose to be Burkean or Mute even if they would choose Heroism if a national consensus authorized it.

For example, someone who believes in moral readings (as did Bickel, emphatically ${ }^{139}$ ) might also believe in prudence, and for that reason might believe that silence is golden if courts seek to preserve their own political capital. In the words of Gerald Gunther, Bickel believed that courts should be "100 percent principled, 20 percent

\footnotetext{
${ }^{134}$ See John Hart Ely, The Wages of Crying Wolf, 82 YALE L.J. 920 (1973).

${ }^{135}$ See RONALD DWORKIN, TAKING RIGHTS SERIOUSLY (1974).

${ }^{136}$ See DWORKIN, LAW'S EMPIRE, supra note.

${ }^{137}$ See ELY, DEMOCRACY AND DISTRUST, supra note.

${ }^{138}$ BICKEL, supra note.

${ }^{139}$ See BICKEL, supra note.
} 
of the time." ${ }^{140}$ Gunther was a critic of Bickel, but a believer in the passive virtues could easily embrace the basic idea. A judge who believes in democracy-reinforcement could similarly agree that there is a time and a place for muteness.

\section{Personae and Ideology}

Commentators often divide judges along political lines, and reasonably so. A great deal of empirical work shows that in ideologically contested cases, Republican appointees vote differently from Democratic appointees, and Republican appointees differ from one another, as do Democratic appointees. ${ }^{141} \mathrm{We}$ should now be able to see that a central division, not involving ideology as such, is among Personae. As noted, Justice Kennedy is often a Hero while Chief Justice Roberts is often a Burkean, while Justice Antonin Scalia is frequently a Hero-Soldier. Consider, for example, Justice Scalia's opinion for the Court in Heller, ${ }^{142}$ invoking the original understanding in support of the view that the Second Amendment creates an individual right.

During and after the Lochner era, the great liberal judges were Soldiers. ${ }^{143}$ Rejecting the heroism of judicial decisions invalidating minimum wage and maximum hour legislation, celebrated Soldiers (above all Justice Holmes ${ }^{144}$ ) argued in favor of judicial deference to legislation. During the Warren Court, by contrast, conservatives assumed the mantle of the Soldier. ${ }^{145}$ They treated the heroic Warren Court decisions of the 1950s and 1960s as a form of hubris. And indeed, a judge can be heroic on a Tuesday (for example, by voting to invalidate a provision of the Voting Rights Act ${ }^{146}$ ) and a Soldier on Wednesday (for example, by voting to uphold the Defense of Marriage $\mathrm{Act}^{147}$ ). The rapid switch from Hero to Soldier might seem to be a form of inconsistency, even hypocrisy, but the appearance may well be misleading, for it need not be anything of the kind. The shift might be an artifact of the judge's theory of interpretation.

Edmund Burke is known of course as one of history's great conservatives, ${ }^{148}$ and to qualify as such, all Burkeans are conservative in the sense that they seek to build incrementally on the past. But some Burkeans (as I am understanding them) build incrementally in a liberal direction, whereas others build incrementally to the right. In

\footnotetext{
${ }^{140}$ See Gerald Gunther, The Subtle Vices of the "Passive Virtues," 64 COLUM. L. REV. 1, 3 (1964).

${ }^{141}$ See LeE EPstein ET AL., The Behavior OF Federal Judges (2013).

${ }^{142}$ District of Columbia v. Heller, 554 U.S. 570 (2008).

${ }^{143}$ See West Coast Hotel v. Parrish, 300 U.S. 379 (1937); NLRB v. Jones \& Loughlin Steel Co., 301 U.S. 1 (1937).

${ }^{144}$ Lochner v. New York, 198 U.S. 45, 65 (1905) (Holmes, J., dissenting).

${ }^{145}$ See, e.g., Frontiero v. Richardson, 411 U.S. 677, 690 (1973) (Rehnquist, J., dissenting); Roe v. Wade, 410 U.S. 113, 171 (1973) (Rehnquist, J., dissenting).

${ }^{146}$ See Shelby Cnty. v. Holder, 133 S. Ct. 2612 (2013).

${ }^{147}$ See United States v. Windsor, 133 S. Ct. 2675, 2697 (2013) (Scalia, J., dissenting).

${ }^{148}$ See JeSSE NORMAN, EDMUND BuRKE: THE First CONSERVATIVE (2013).
} 
many areas, Byron White was a liberal Burkean, ${ }_{150}^{149}$ while Chief Justice Roberts is a conservative one, as was Sandra Day O'Connor. ${ }^{150}$

There are multiple theories of constitutional muteness, and they need have no political valence. We have seen that some judges embrace an account of Article III, grounded in text and history, that forbids courts from issuing advisory opinions or hearing generalized grievances. ${ }^{151}$ That account would produce a number of Mute decisions. But we have also seen that by emphasizing "the passive virtues," Bickel meant to draw attention to, and to embrace, quite pragmatic and strategic uses of silence, designed to limit the occasions for judicial intervention into the political domain. ${ }^{152}$ Bickel did not contend that his own account was required by the text of Article III; his emphasis was on prudence.

On one view, muteness is an extreme point on the same continuum with Burkeanism, reflecting a form of judicial statesmanship, and Mutes are Burkeans with less courage (or more prudence). What is clear is that the passive virtues can be enlisted in the service of either conservative or progressive goals.

\section{Choosing A Persona} question?

Which Persona is best? Is it possible to offer criteria by which to answer that

\section{A. The Right Theory}

I have suggested that the answer lies in the identification of the right theory of constitutional interpretation. If originalism is the right theory, the appropriate Persona will be an artifact of that theory. So too with judges who embrace a democracyreinforcing approach to judicial review, or who insist on a moral reading. The correct theory is logically prior to the choice among the Constitutional Personae, who may well appear as they do because of the theory that lies in the background. ${ }^{153}$

This is particularly easy to see for Heroes and Soldiers; both of these Personae will "fall out" of the prevailing theory of interpretation. Which Persona falls out of any particular theory will depend on the nature of the particular question. The same is true for Burkeans and Mutes. We could have a Burkean theory of interpretation, seeing constitutional law as closely akin to the common law. ${ }^{154}$ Even if a judge believes that a Burkean theory is only part of the picture, and unlikely to be complete, Burkean

\footnotetext{
${ }^{149}$ See Dennis Hutchinson, The Man Who Was Whizzer White: A Portrait of Justice BYRON R. WHITE (1998).

${ }^{150}$ See SUNSTEIN, ONE CASE AT A TIME, supra note, for references.

${ }^{151}$ See, e.g., Scalia, The Doctrine of Standing As An Essential Element of the Separation of Powers, supra note.

${ }^{152}$ See BICKEL, supra note.

${ }^{153}$ I have noted, however, that a Persona may be adopted for strategic reasons.

${ }^{154}$ See DAVID A. STRAuSS, THE LiVING CONSTITUTION (2010).
} 
considerations, counseling prudence, might make Burkeans out of those who also have enthusiasm for some other theory of interpretation. If an originalist believes in the claims of precedent, he might sound like a Burkean, and to the extent that he is willing to abandon the original understanding to protect precedent, he might even turn out to be a Burkean, at least in particular cases. ${ }^{155}$ We have seen that muteness may be a product of originalism, but it might also be part of an account of interpretation that allows a place for silence.

It would be possible to end simply by insisting that the choice of Personae must be parasitic on the choice of a theory of interpretation (bracketing psychological or strategic factors that may lead a judge to favor a particular Persona). But that claim leaves open the question about how to make that choice. ${ }^{156}$ On that question, a few remarks will be in order.

\section{B. What's Interpretation?}

Some people insist that the very idea of interpretation leads to a particular account of what judges must do to claim that they are engaged in the interpretive enterprise. Perhaps interpretation, to qualify as such, entails a search for the original "intent"157 or the original public meaning, ${ }^{158}$ or instead for a judgment that puts the existing legal materials in the best constructive light. ${ }^{159}$ If so, the idea of interpretation generates the appropriate theory, which in turn produces the relevant Persona.

It is true that some activities cannot be counted as interpretation at all. If a judge disregards the constitutional text and rules however he sees fit, he is not engaged in interpretation. But it is false to say that the idea of interpretation, as such, makes the choice among competing approaches. A judge who is committed to interpretation might nonetheless choose to disregard the original intent in favor of the original understanding - or vice-versa. Such a judge might emphasize specific and concrete understandings or instead understandings that are more abstract and general ${ }^{160}$ — or vice-versa. Such a judge may or may not favor moral readings. There is nothing in the idea of interpretation that resolves real debates among competing theories or about competing Personae.

${ }^{155}$ See Antonin Scalia, Originalism: The Lesser Evil, 57 U. CIN. L. REV. 849, 861-64 (1989) (embracing "faint-hearted originalism" in light of the claims of precedent).

${ }^{156}$ See Adrian Vermeule, Interpretive Choice, 75 N.Y.U. L. REV. 74 (2000).

${ }^{157}$ See Walter Benn Michaels, In Defense of Old Originalism, 31 W. New ENG. L. REV. 21 (2009), and in particular this suggestion: "[Y]ou can't do textual interpretation without some appeal to authorial intention and, perhaps more controversially, you can't (coherently and non-arbitrarily) think of yourself as still doing textual interpretation as soon as you appeal to something beyond authorial intention-for example, the original public meaning or evolving principles of justice." Id. at 21.

${ }^{158}$ Saikrishna Prakash, Radicals in Tweed Jackets: Why Extreme Left-Wing Law Professors Are Wrong for America, 106 COLUM. L. REV. 2207 (2006).

159 See DWORKIN, LAW's EMPIRE, supra note (contending that interpretation involves tasks of "fit" and "justification").

${ }^{160}$ See JACK BALKIN, LIVING ORIGINALISM (2011). 


\section{Errors}

As a first approximation, the choice is an inescapably pragmatic one, and it turns on the magnitude and number of errors ("error costs"). ${ }^{161}$ Suppose that Heroes move society in the right direction, because they have the right conception of liberty and equality. If so, it would seem to follow that judges should be heroic. ${ }^{162}$ But suppose that judicial Heroes are error-prone and that Burkeans would do far better, in the sense that they would make fewer and less damaging mistakes. If so, Burkeanism is preferable, because it is safer insofar as it minimizes the seriousness of errors.

However simple, these points suggest the need for a comparative assessment, involving the judgments of judges and of those whom they would displace. ${ }^{163}$ In a world in which judges systematically err and in which democratic processes do well, the argument for Soldiers would be very strong. In a world in which judges are excellent at correcting for democratic deficits - for example, by safeguarding rights that are indispensable to well-functioning political process - a democracy-reinforcing conception of review, overseen by Heroes, would be difficult to contest. The argument for such Heroes would be weakened if judges are unable to unwilling to undertake that task. There is no acontextual argument on behalf of Heroes or Soldiers, and nothing in the idea of interpretation can settle the choice.

An evident complication is that to know whether we have error costs, we need an account by which to identify error. Suppose that democratic self-government is one of the rights to which people are entitled. If so, the arguments for Soldiers are strengthened. Those who reject soldiering might respond that the ideal of self-government has its own internal morality, ${ }^{164}$ and that an imperfectly democratic process, or a process that fails to respect basic rights, calls for heroism not in opposition to democracy but in its name. ${ }^{165}$ Originalists might want to insist that to be worthy of the name, Soldiers do not merely implement legislative will. They must follow the will of We the People as well, and that approach will call for invalidation of democratic outcomes, and indeed for decisions that might be mistaken for heroism. ${ }^{166}$ Hero-Soldiers - they will insist - are Soldiers, not Heroes at all. ${ }^{167}$

An independent complication involves the level of generality at which judges are choosing among Personae. It is hard to make an across-the-board judgment in favor of Heroism or Muteness, but a judge might be confronted with a decision whether to be a Soldier in general or only in particular cases, and the same decision might be made by a judge contemplating Burkeanism. A judge could plausibly conclude that some provisions

\footnotetext{
${ }^{161}$ To the same general effect, see Vermeule, supra note.

${ }^{162} \mathrm{I}$ am bracketing the question whether self-government is one of the rights that people have and whether and when Heroism is objectionable for that reason.

${ }^{163}$ See Vermeule, supra note.

${ }^{164}$ See DWORKIN, supra note.

${ }^{165} \mathrm{Id}$.

${ }^{166}$ See Scalia, Originalism: The Lesser Evil, supra note.

${ }^{167}$ For an empirical test, see Cross, supra note.
} 
and some occasions call for soldiering, but that others do not, and that no categorical judgment for or against soldiering would make sense.

To be sure, some advocates of soldiering argue vigorously on behalf of a categorical or general choice in favor of the Soldier. ${ }^{168}$ They may be correct, but an evaluation of their view, and of whether a general commitment to soldiering is preferable to a case-by-case judgment about whether soldiering makes sense in the circumstances, requires an assessment of the magnitude and number of errors associated with the competing approaches. ${ }^{169}$ The same can be said for Burkeans. Perhaps a Burkean approach makes sense for the Due Process Clause but not for the Equal Protection Clause, ${ }^{170}$ or perhaps such an approach is best for the Constitution as a whole. Here too an assessment of error costs is inescapable.

\section{Conclusion}

Constitutional law is populated the Four Personae, who argue with one another in a wide variety of periods and contexts. For example, we can find debates between Heroes and Soldiers in disputes over substantive due process, ${ }^{171}$ free speech, ${ }^{172}$ and property rights ${ }^{173}$; Heroes and Mutes are often in conflict. ${ }^{174}$ Because the arguments of the Four Personae are easily identifiable, at least in the abstract, an understanding of those arguments, and of their characteristic features, helps to illuminate the enduring nature of constitutional disagreement.

Different theories of constitutional interpretation can lead judges to adopt one or another of the Personae, depending on the controversy. Hence it should be no surprise, and no cause for embarrassment, if a judge turns out to be a Hero on Monday and a Soldier on Tuesday. We can also find incompletely theorized agreements ${ }^{175}$ in favor of heroism, soldiering, Burkeanism, or muteness - as, for example, when judges with different methodological commitments converge on silence. ${ }^{176}$ And while I have contended that a theory of constitutional interpretation is logically prior to the choice of a Persona, it is not at all unreasonable to speculate that a Persona might be adopted for strategic reasons, or that a Persona might have special appeal for psychological reasons.

No judgment about the role of the courts, or about Constitutional Personae, can sensibly be made in the abstract, or independently of concrete judgments about what can

\footnotetext{
${ }^{168}$ See Vermeule, supra note.

${ }^{169}$ This is a version of the familiar choice between rules and standards. See Louis Kaplow, Rules Versus Standards: An Economic Analysis, 42 DUKE L.J. 557 (1992).

${ }^{170}$ See Cass R. Sunstein, Sexual Orientation and the Constitution: A Note on the Relationship Between Due Process and Equal Protection, 55 U. CHI. L. REV. 1611 (1988)

${ }^{171}$ See Roe v. Wade, 410 U.S. 113 (1973).

${ }^{172}$ See New York Times v. Sullivan, 376 U.S. 254 (1964).

${ }^{173}$ See Lucas v. S.C. Coastal Council, 505 U.S. 1003 (1992).

${ }^{174}$ See, e.g., United States v. Windsor, 113 S. Ct. 2675 (2013).

${ }_{175}^{17}$ See Cass R. Sunstein, Incompletely Theorized Agreements, 108 HARV. L. REV. 1733 (1995).

${ }^{176}$ See Hollingsworth v. Perry, 113 S. Ct. 2652 (2013).
} 
be counted as a mistake, and about who is likely to be trustworthy. In some imaginable worlds, Heroes are heroes; in others, they are hardly that, and they may even be villains. In some imaginable worlds, Soldiers respect democracy without jeopardizing anything of importance; in others, they leave fundamental rights vulnerable to unreliable majorities. In some imaginable worlds, Burkeans strike the proper balance between self-government and other values; in others, they are far too cautious, and their incrementalism is a vice. In some imaginable worlds, Mutes make silence golden; in others, they capitulate to the worst forms of injustice and overreaching. The right Persona depends on the plot of the play. 